\title{
Experiences of workplace bullying among 'non-traditional' students: Cause for concern for both business and education?
}

\author{
Conor Mc Guckin ${ }^{1 *}$, Christopher Alan Lewis ${ }^{2}$, Mark Shevlin ${ }^{3}$ and Garry R. Prentice ${ }^{4}$ \\ ${ }^{I}$ School of Education, Trinity College Dublin, Dublin 2, Ireland ${ }^{2}$ Division of Psychology, School of \\ Health Sciences, Glyndŵw University, Wales ${ }^{3}$ School of Psychology, University of Ulster at Magee \\ College, Northern Ireland ${ }^{4}$ Department of Psychology, Dublin Business School, Dublin 2, Ireland.
}

(Received January 16, 2013; Accepted April 25, 2013)

\begin{abstract}
Workplace bullying (WPB) has been identified as an insidious aspect of the contemporary work environment (Einarsen, Höel, Zapf, \& Cooper, 2003). The present study had three related aims (i) to determine current and prior personal experience of WPB among a sample of 295 adults returning to tertiary education, (ii) to further explore the 'work environment hypothesis' (Einarsen, Raknes, \& Matthiesen, 1994; Mc Guckin, Lewis, \& Shevlin, under review) as an antecedent in the WPB process by examining the relationship between the 'psychosocial workplace' and exposure to WPB (Varhama \& Björkqvist, 2004a, b; Varhama et al., 2010), and (iii) to explore the relationship between exposure to WPB and salient work and life attitude variables (Mc Guckin et al., under review). Overall, 32.4\% $(n=93)$ of the respondents had been bullied in the previous 6 months, $42.1 \%(n=120)$ had witnessed colleagues being bullied during this period, and $56.8 \%(\mathrm{n}=162)$ had been bullied in their previous career. The collective influence of the hypothesised antecedent variables (i.e., 'Challenge', 'Social Climate', 'Leadership', 'Work Control', 'Work Load', 'Role Conflict', and 'Role Ambiguity') explained a significant proportion of the variance in relation to self-reported personal experience of workplace bullying. Exposure to workplace bullying was significantly related to impaired 'work and life attitudes'.
\end{abstract}

Keywords: workplace, bully, victim, non-traditional, students.

Experiencias de bulling en el lugar de trabajo entre estudiantes 'no tradicionales': ¿Motivos de preocupación para la empresa y la educación?

ABSTRACT: El bullying en el lugar de trabajo (WPB) ha sido identificado como un aspecto insidioso de los ambientes de trabajo contemporáneos (Einarsen, Höel, Zapf, y Cooper, 2003). El presente estudio tuvo tres objetivos (i) determinar la experiencia previa y actual de bullying en el trabajo entre una muestra de 295 adultos que retomaron la educación terciaria, (ii) profundizar en la 'hipótesis del ambiente de trabajo’ (Einarsen, Raknes, y Matthiesen, 1994; Mc Guckin, Lewis, y Shevlin, under review) como un antecedente en el proceso de WPB, examinando la relación entre 'el ambiente psicosocial en el lugar de trabajo' y la exposición a WPB (Varhama \& Björkqvist, 2004a, b; Varhama et al., 2010), y (iii) explorar la relación entre la exposición al WPB y las variables de actitudes 
más sobresalientes hacia la vida y el trabajo (Mc Guckin et al., under review). En general, 32.4\% $(\mathrm{n}=93)$ de los participantes se había visto acosado en los 6 meses previos, $42.1 \%(n=120)$ habían sido testigos del acoso de colegas durante el mismo periodo, y el $56.8 \%(n=162)$ se habían visto acosados en su trayectoria profesional anterior. La influencia colectiva de las variables antecedentes hipotetizadas (i.e., 'Desfío', 'Clima Social', 'Liderazgo', 'Supervisión del Trabajo', 'Carga de Trabajo', 'Conflicto de Rol', y 'Ambigüedad de Rol') explicó una importante proporción de la varianza en relación con la experiencia personal autoinformada de bullying en el lugar de trabajo. La exposición al bullying en el trabajo estuvo significativamente relacionada con la insatisfacción de actitudes hacia la vida y el trabajo.

Keywords: lugar de trabajo, bully (Acosar), victima, estudiantes no tradicionales.

In the ever changing workplace, good interpersonal relationships with fellow colleagues and superiors are vital. From an employee's perspective, such positive working relationships are fundamental to physical health and psychological well-being. From an employer's perspective, these relationships are important in the form of increased productivity, reduction in absenteeism, and avoidance of costly court cases. Research has demonstrated that bullying behaviours represent one form of extreme negative social interaction at work (Vartia, 1996). Indeed, on an international level, workplace bullying has been recognised as a serious problem in the working environment (see Einarsen, Höel, Zapf, \& Cooper, 2003).

Knowledge regarding the prevalence of workplace bullying has been provided through detailed research studies in many European countries (e.g., Sweden: 3.5\% [Leymann, 1996]; Norway: 10\% [Vartia, 1991]; Finland: 16\% [Björkqvist, 1992]; Austria: $17.5 \%$ - 26.6\% [Niedl, 1995]). In the UK, whilst Höel, Cooper, and Faragher (2001) report an incidence rate of 10.6\%, Rayner (1997) reported a rate of 14\%. In Ireland, the Health and Safety Authority's 'National Survey of the Task Force' (2001) found that 7\% of respondents reported being the victim of workplace bullying within the preceding 6 month period $(\mathrm{N}=5,252)$.

Whilst research endeavors have sought to explore the nature, incidence, correlates, and prevention of workplace bullying among various occupational groupings (e.g., nurses [Mc Guckin, Lewis, \& Shevlin, under review], prison officers [Vartia \& Hyyti, 2002]), as well as those individuals that have been forciblyexcluded from the workforce (i.e., bullied out of the employment: O'Moore, Seigne, McGuire, \& Smith, 1998), Mc Guckin et al. (under review) argue that similar attention is required in relation to those individuals that have been selfexcluded from the workplace (e.g., returning tertiary education students), so as to further understand the sequelae of the phenomenon. 
Non-traditional students returning to tertiary education: the focus of the current research

The traditional unidirectional link between education and the workplace, whereby students leave education to participate in the workforce, has been replaced with a bi-directional model that sees a greater emphasis on life-long learning within a learning society. This change is also reflected in the evidenced larger numbers of workers returning to education after having left to participate in the workforce. This has been seen, for example, within the UK (Thomas, 2001) and Ireland (Higher Education Authority, 2009). In Ireland, for example, the number of mature $(23+)$ new entrants to tertiary education courses increased by $6.1 \%$ between 2006/2007 and 2007/2008. Indeed, across the European 'Higher Education Arena', there has been consensus that the criteria for access and admission to higher education courses be modernised so that they are suitably flexible and attractive so as to widen participation opportunities for adult learners (e.g., the UK Department for Education and Skills' 2003 policy on 'The Future of Higher Education'). This cross-national level of governmental commitment has also been matched by the growing impetus amongst adult 'non-traditional students' (Dill \& Henley, 1998) themselves to make this return to education. Indeed, in times of economic uncertainty, many in the workforce seize the opportunity to re-skill themselves for the new requirements of the economy and secure better employment prospects. However, what is unclear is whether the decision to exit the workforce and return to higher education is related to personal experience of workplace bullying.

Whilst previous research has explored the nature, incidence, correlates, and prevention of workplace bullying among various cohorts of workers and school students, thus far there has been scant attention paid to the workplace experiences and personal motivations of students who decide to exit the workforce, either full- or part-time, to increase their education at tertiary level (Mc Guckin et al., under review).

In an American study of mistreatment at work among 59 young workers attending college courses, all respondents reported exposure to some kind of mistreatment at their current workplace (Keashly, Trott, \& MacLean, 1994). Approximately $14 \%$ reported experiencing at least 10 different kinds of abusive events in their current work situation.

Among 1,137 mature students sampled at one English university, Rayner (1997) found that just over half (53\%) of the sample reported being bullied 'at some time during their working life'.

In response to Mc Guckin et al. (under review) regarding the dearth of research in this important area, the current research explores the personal experiences of workplace bullying among a sample of returning tertiary education students. 


\section{'Cause' and 'effect' in workplace bullying}

Like bully/victim problems among school pupils (Barker et al., 2008; Brunstein Klomek et al., 2007; Cook et al., 2010; Hodges \& Perry, 1999; KaltialaHeino, Rimpela, Rantanen, \& Rimpela, 2000; Lund et al., 2009; Rigby, 2001, 2002; Salmivalli, 2001), knowledge of the salient 'cause' and 'effect' variables in relation to workplace bullying has increased dramatically over the past number of years. In terms of causal factors, Zapf (1999) argues that the organization, the social system, a certain perpetrator, and the victim have to be considered as potential causes of workplace bullying. In support, Einarsen (1999) has identified the important roles of (i) the victim's personality and (ii) psychosocial factors. For example, Björkqvist, Österman, and Hjelt-Bäck (1994) identified (i) competition concerning status and job positions, (ii) envy, and (iii) the aggressor being uncertain about his/her self as causal factors in workplace bullying episodes. Negative consequences have been particularly evident with regard to individuals in terms of their health (Niedl, 1996; O'Moore et al., 1998) and also their level of job satisfaction (Einarsen \& Raknes, 1997). In addition, research has highlighted the negative effects for organizations caused by workplace bullying: for example, higher absenteeism, higher turnover, higher intent to leave, and earlier retirements (Leymann, 1996; Rayner, 1997). Indeed, the link between bully/victim status in the schoolyard and subsequent bully/victim status in the workplace has recently been examined (Smith, Singer, Höel, \& Cooper, 2003).

\section{Antecedents of workplace bullying: The role of the work environment}

In relation to the identification of antecedent variables in the bullying process, Einarsen, Raknes, and Matthiesen (1994) report that whilst other causal models of workplace bullying have been identified (e.g., victim / bully personality: Brodsky, 1976; Coyne, Seigne, \& Randall, 2000; Leymann, 1992; Olweus, 1991; Thylefors, 1987), the causal model that has received most public attention in Scandinavia emphasises the quality of the organization's work environment (as perceived by the employees) as the main determinant of such behaviours (Einarsen, 1996; Leymann, 1992; Seigne, 1998; Vartia, 1996; Vartia \& Hyyti, 2002; Zapf, Knorz, \& Kulla, 1996). Among a sample of 2,215 Norwegian members of six labour unions, Einarsen et al. (1994) tested the role of variables hypothesised as being part of the 'work environment hypothesis' (i.e., 'Challenge', 'Social Climate', 'Leadership', 'Work Control', 'Work Load', 'Role Conflict', and 'Role Ambiguity'). Einarsen et al. (1994) found that experience of bullying and harassment correlated significantly with 'lack of constructive leadership', 'elevated level of role conflict', 'dissatisfaction with social climate', and 'lack of possibilities to monitor and control one's own work'. These findings were also consistent among observers of bullying incidents.

Whilst not directly testing Einarsen et al.'s (1994) 'work environment hypothesis', other studies have provided support for the notion that varying as- 
pects of the work environment act as antecedent variables in the bullying process (Breen \& Mc Namara, 2004; O’Moore et al., 1998; Vartia, 1996; Vartia \& Hyyti, 2002; Zapf et al., 1996). In their research exploring antecedent and outcome variables among a sample of UK and Irish nurses ( $\mathrm{N}=205)$, Mc Guckin et al. (under review) directly tested Einarsen et al.'s (1994) seminal 'work environment hypothesis'. Whilst finding support for the role of 'Work Challenge', 'Social Climate', and 'Role Ambiguity', the results also demonstrated that 'Leadership', 'Work Control', 'Work Load', and 'Role Conflict' were the least important predictors - a direct contradiction of Einarsen et al.'s (1994) results. In concluding, Mc Guckin et al. (under review) asserted that whilst Einarsen et al.'s (1994) 'work environment hypothesis' was a useful conceptualisation, their results highlighted the need for further research to explore other potential antecedent variables in the bullying process. Considering that the purpose of research designed to identify antecedent 'trigger' variables in the bullying process is to aid 'risk assessment' and 'risk management' in terms of intervention and prevention (Cox, 2005), Mc Guckin et al. (under review) suggest that aspects of the 'psychosocial work environment' (e.g., conflict, burnout, work harassment, work atmosphere, work stress, sexual harassment, and alcohol abuse) may also act as antecedent variables in the bullying process. Varhama and Björkqvist (2004a, b) and Varhama et al. (2010) have demonstrated the relationship between workplace bullying and these aspects of the psychosocial work environment among samples of Finnish, Polish, and Spanish employees. One of the aims of the present research is to extend this previous research by exploring the relationship between these hypothesised psychosocial work environment variables and experiences of bullying behaviours.

\section{Effects of workplace bullying: Work and life attitudes}

Brodsky (1976) alerted us to the fact that "the effects of harassment upon its victims can be devastating" (p. 38). As a serious source of social stress, exposure to workplace bullying has been demonstrated to be associated with impaired health and well-being, as well a reduction in positive attitudes to work and life attitudes (Björkqvist et al., 1994; Breen \& Mc Namara, 2004; Brodsky, 1976; Einarsen, 2000; Einarsen, Matthiesen, \& Skogstad, 1998; Einarsen \& Raknes, 1997; Einarsen, Raknes, Matthiesen, \& Hellesøy, 1996; Kivimäki et al., 2003; Leymann, 1988; Leymann \& Gustafsson, 1996; Lynch \& O’Moore, 2004; Mikkelsen \& Einarsen, 2002; O’Moore et al., 1998; Quine, 1999; Thylefors, 1987; Voss, Floderus, \& Diderichsen, 2001; Zapf et al., 1996). Indeed, whilst Kivimäki et al. (2003) and Voss et al. (2001) report that workplace bullying has been related to a $25 \%$ to $90 \%$ increase in the risk of recorded sickness absence, Leymann (1990a, 1992) has claimed that work harassment is a major cause of suicide. Thus, in conjunction with assessing the possible role that the psychosocial work environment may have in the bullying process, it is also necessary to assess the work and life attitudes of victims of such behaviours. 
In their research exploring the role of the 'work environment hypothesis' in the bullying process, Mc Guckin et al. (under review) also explored whether experience of workplace bullying was predictive of self-reported attitudes towards various aspects of work and personal-life (i.e., job satisfaction, organizational commitment, interpersonal trust at work, work involvement, intrinsic job motivation, self-rated anxiety, life satisfaction). Results from their research demonstrated the overwhelming effects of workplace bullying in relation to 'Work Involvement', 'Intrinsic Job Motivation', 'Life Satisfaction', 'Interpersonal Trust at Work', 'Self Rated Anxiety', 'Job Satisfaction', and 'Interpersonal Trust at Work'. One of the aims of the present research is, therefore, to explore the relationship between previous experience of victimization in the workplace and the quality of work and life attitudes of these returning tertiary students.

\section{Study aims}

The study had three aims. Firstly, to record the incidence and experiences of workplace bullying among a sample of 'non-traditional' students who have returned to tertiary level education. Secondly, to supplement previous research that has explored the role of the 'work environment hypothesis' in the bullying process by examining the 'psychosocial workplace'. Thirdly, to explore the relationship between personal experience of workplace bullying and attitudes towards various aspects of work and personal-life.

\section{METHOD}

\section{Respondents}

Respondents were 295 non-traditional (i.e., 'mature') full- and part-time undergraduate students studying psychology. The full-time students $(28.5 \%, \mathrm{n}=$ 84) were recruited at Magee College, University of Ulster, Northern Ireland. The part-time students $(71.5 \%, \mathrm{n}=211)$ were Open University (UK) students and were recruited at a course required residential school (the students were predominantly residents of the British Isles). The full-time students were either still engaged with their employer or had recently exited the workforce. The timing of the survey administration at the start of the academic year accommodated the need for these respondents to be able to reflect upon the requirement to answer questions regarding their experiences in the workforce during the previous six months. The part-time students were all studying concurrently with their daily employment and were, thus, able to answer questions relating to the specified time reference period for reflection upon events occurring in their workplace. Whilst $17.2 \%(n=50)$ of respondents were male, $82.8 \%(n=240)$ were female. Five respondents declined to answer this question. The mean age was 36.20 years $(\mathrm{SD}=10.06)$. Just over two fifths $(41.6 \%, \mathrm{n}=113)$ held positions that could be classified as supervisory, clerical, or skilled manual. Just over one tenth 
$(10.3 \%, \mathrm{n}=28)$ could be classified as semi- / unskilled workers or casual / low grade workers.

\section{Instruments administered}

All respondents completed a questionnaire booklet containing three sections:

\section{Section 1}

To determine personal experience of bullying behaviour, respondents were introduced to Einarsen et al.'s (1994, p. 387) definition of bullying before completing three bullying related questions:

(i) "Based on the above definition, do you think that you have been subjected to bullying behaviour in your workplace during the last 6 months?" Response options ranged from 'No', through 'Seldom', 'Now and Then', 'About Once a Week', 'Many Times', to 'Not Applicable' (e.g., that the respondent worked in isolation from colleagues).

(ii) Have you seen others being subjected to bullying at your workplace during the last six months? Response options were: 'No', 'Yes', and 'Not Applicable'.

(iii) "Have you ever been bullied (at any time) in your career?" Response options were: 'No' and 'Yes'.

\section{Section 2}

Respondents were asked to complete measures hypothesised to represent antecedent variables (i.e., psychosocial work environment) in the bullying process.

(i) The Work Atmosphere Scale (Björkqvist \& Österman, 1992b): Across a five-point scale $(0=$ 'Never' to $4=$ 'Very Often'), respondents assess how they feel about 14 aspects of their workplace at the time of administration. Examples of items include: 'Everybody gets the appreciation (s)he deserves' (Item 2) and 'There are people checking on others' working hours, although it is none of their business' (Item 6). Internal stability has been demonstrated for a Portuguese adaption of the Scale by dos Santos Palazzo, Carlotto, and de Castro (2012) (Cronbach $\alpha=0.67$ ). In the current study, the scale demonstrated acceptable internal consistency (Cronbach $\alpha=0.61$ ).

(ii) The Work Stress Symptom Scale (Björkqvist \& Österman, 1992c): Across a five-point scale $(0=$ 'Never' to $4=$ 'Very Often'), respondents are asked if, due to stress, have they suffered from any of the 10 symptoms during the last 12 months. Examples of items include: 'Weariness and feebleness' (Item 3) and 'Reduced self-confidence' (Item 10). Internal stability has been demonstrated for the Scale by Lin (2007) (Cronbach $\alpha=0.98$ for victims; Cronbach $\alpha=0.95$ for non-victims). In the current study, the scale demonstrated acceptable internal consistency (Cronbach $\alpha=0.93$ ). 
(iii) The Psychosocial Workplace Inventory (Björkqvist \& Österman, 1992d) defines what is meant by the key terms in the inventory (i.e., conflict, burnout, work harassment, sexual harassment, and alcohol abuse) and then asks whether the respondent has had experiences of this and to what degree (on three levels of severity). The validity of the Inventory has been demonstrated by Björkqvist, Österman, Ingo, and Varhama (2007). In the current study, the Work Harassment Scale demonstrated acceptable internal consistency (Cronbach $\alpha=0.97$ ).

\section{Section 3}

Respondents were asked to complete measures hypothesised to represent outcome variables (i.e., work and life attitudes) in the bullying process.

(i) Work and Life Attitudes: Scales designed to assess various components of work and life attitudes were drawn from Warr, Cook, and Wall's (1979) Work and Life Attitudes Survey (i.e., Work Involvement, Intrinsic Job Motivation, Job Satisfaction, Self-Rated Anxiety, and Life Satisfaction) and Cook and Wall's (1980) supplement to Warr et al.'s (1979) compendium (i.e., Interpersonal Trust at Work and Organizational Commitment). The Work Involvement Scale (e.g., 'Having a good job is very important to me': Item 2), Intrinsic Job Motivation Scale (e.g., 'I feel a sense of personal satisfaction when I do this job well': Item 1), Interpersonal Trust at Work Scale (e.g., 'I can trust the people I work with to lend me a hand if I need it': Item 5), and Organizational Commitment Scale (e.g., 'I am quite proud to be able to tell people who it is I work for': Item 1) were scored on a 5-point response format, ranging from 1 'Strongly Disagree' to 5 'Agree Strongly' (higher scores indicative of greater levels of the concept). Whilst the 5-point response formats for the Job Satisfaction Scale (e.g., 'Your opportunity to use your abilities': Item 8) and the Life Satisfaction Scale (e.g., 'The way you spend your leisure time': Item 4) ranged from 1 'Very Dissatisfied' to 5 'Very Satisfied' (higher scores indicative of greater levels of the concept), the 5-point response format for the Self-Rated Anxiety (e.g., 'Not having enough money for day to day living': Item 1) scale ranged from 1 'Not Concerned' to 5 'Very Worried', with higher scores indicative of greater levels of self-rated anxiety. The scales have all demonstrated adequate psychometric properties (Bond \& Bunce, 2000; Hermann, 2008; Warr et al., 1979). For cultural and / or applicability reasons, certain items from the Interpersonal Trust at Work Scale, the Organizational Commitment Scale, the Life Satisfaction Scale, and the Self-Rated Anxiety Scale were removed for the current research. In the current study, the Work Involvement, Intrinsic Job Motivation, Job Satisfaction, Self-rated Anxiety, Life Satisfaction, Interpersonal Trust at Work, and Organizational Commitment scales demonstrated acceptable internal consistency (Cronbach $\alpha=0.71,0.84,0.92$, $0.74,0.84,0.69,0.61$ respectively).

(ii) Self-esteem: Respondents completed measures of 'state' self-esteem (State Self-Esteem Scale: Heatherton \& Polivy, 1991) and 'trait' self-esteem (SelfEsteem Scale: Rosenberg, 1965). 
Heatherton and Polivy's (1991) 20-item State Self-Esteem Scale asks respondents to rate how they feel 'right now' in relation to their self-worth in the domains of Academic Performance, Social Evaluation, and Appearance (e.g., Item 1: 'I feel confident about my abilities'). Scored on a scale ranging from 1 'Not at All' to 5 'Extremely', responses are averaged to arrive at a unitary state selfesteem score with higher overall scores reflective of higher states of self-esteem. Heatherton and Polivy (1991) conclude that their development studies "... provide some evidence that the SSES is psychometrically sound." (p. 899). In the current study, the scale demonstrated acceptable internal consistency (Cronbach $\alpha=0.92$ ).

Rosenberg's (1965) Self-Esteem Scale is a brief and easily administered 10item unidimensional measure of global self-esteem (e.g., Item 5, reverse scored: 'I feel that I do not have much to be proud of'). Scored on a scale ranging from 1 'Strongly Disagree' to 4 'Strongly Agree', responses are averaged to arrive at a unitary trait self-esteem score with higher overall scores reflective of higher levels of self-esteem. Diverse studies have demonstrated the reliability and validity of the instrument (e.g., Fleming \& Courtney, 1984; Keith \& Bracken, 1996; Silber \& Tippett, 1965; Wylie, 1989). In the current study, the scale demonstrated acceptable internal consistency (Cronbach $\alpha=0.91$ ).

\section{Design and procedure}

All measurement instruments were compiled into one questionnaire booklet for ease of completion by the respondent. Questionnaires were distributed and collected at each education location by the same researcher so as to maintain consistency, encourage participation, and answer any questions. Anonymity was assured by indicating that no information should be included that may identify either the respondent, the organization, or any other persons or places. Respondents were assured of their right to withdraw at any time.

\section{Analysis}

Multiple linear regression using the Enter method and logistic regression analyses were conducted in a series of stages so as to explore the study hypotheses.

\section{RESULTS}

\section{Personal experience of bullying}

The first aim of the current research was to explore the incidence of personal experience of bullying behaviours. Whilst approximately one-third of respondents $(32.4 \%, \mathrm{n}=93)$ reported that they had been bullied in the 'previous six months' (i.e., either 'seldom', 'now and then', 'about once a week', or 'many 
times'), 42.1\% $(\mathrm{n}=120)$ reported that they had witnessed a colleague being bullied during this time-reference period. Additionally, 56.8\% $(\mathrm{n}=162)$ reported that they had been bullied previously in their career.

\section{Psychosocial workplace}

The second aim of the current research was to explore whether the hypothesised antecedent variables (i.e., work harassment, sexual harassment, atmosphere, stress, conflict, burnout, and alcohol abuse) would be significantly associated with personal experience of bullying behaviours. Each of these variables were included in three multiple regressions (Linear regression for variable [i] and binary logistic regressions for variables [ii] and [iii]) using the 'Enter' method so as to explore the collective and individual influence of these variables on each of the three predicted outcome variables: (i) 'Do you think that you have been subjected to bullying behaviour in your workplace during the last six months?', (ii) 'Have you seen others being subjected to bullying at your workplace during the last six months?', and (iii) 'Have you ever been bullied [at any time] in your career?'.

First, the collective influence of the hypothesised antecedent variables on the first of the predicted outcome variables (i.e., having been bullied in the previous six months) was 0.38 (adjusted $\mathrm{r}^{2}$ ). Whilst the collective influence of these hypothesised antecedent variables explained a significant proportion of the variance in the outcome variable, statistically significant relationships were uncovered in relation to work harassment, both on The Work Harassment Scale (Björkqvist \& Österman, 1992a) (Standardized b $=0.49, \mathrm{p}<0.01$ ), and The Psychosocial Workplace Inventory (Björkqvist \& Österman, 1992d) (Standardized b $=-0.17, \mathrm{p}<0.01)($ See Table 1$)$.

Table 1. Linear Regression Parameters for Predicting the Outcome 'Been Bullied in the Last Six Months,

\begin{tabular}{lrrrrc}
\hline Predictor & $\beta$ & $S E \beta$ & $\begin{array}{c}\text { Standardised } \\
\text { Constant }\end{array}$ & \multicolumn{1}{c}{$\mathrm{t}$} & $p$ \\
Stress & 0.25 & 0.43 & & 0.60 & 0.552 \\
Alcohol & 0.02 & 0.01 & 0.14 & 1.71 & 0.088 \\
Atmosphere & -0.07 & 0.28 & -0.01 & -0.25 & 0.801 \\
Sexual Harassment & 0.01 & 0.01 & 0.05 & 0.81 & 0.419 \\
Burnout & -0.35 & 0.11 & -0.17 & -3.06 & 0.002 \\
Work Conflict & -0.01 & 0.13 & -0.00 & -0.06 & 0.950 \\
Work Harassment & 0.20 & 0.12 & 0.11 & 1.63 & 0.104 \\
& 0.74 & 0.10 & 0.49 & 7.45 & 0.000 \\
\hline
\end{tabular}

Second, in relation to the second predicted outcome variable (i.e., having seen others being subjected to bullying behaviour at work during the previous six months), the collective influence of the hypothesised antecedent variables was 
significant $\left(\chi^{2}=77.85, \mathrm{df}=14, \mathrm{p}<0.001\right)$. Statistically significant relationships were uncovered in relation to enquiries about 'exposure to work harassment' (Wald $\chi^{2}=18.87, \mathrm{df}=3, \mathrm{p}<0.001$ ), and 'conflicts in the workplace' (Wald $\chi^{2}$ $=14.09$, df $=2, \mathrm{p}<0.01$ ) (See Table 2). In relation to 'exposure to work harassment' odds ratios $\left(e^{\mathrm{b}}\right)$ for Level 1 (4.96), Level 2 (8.04), and Level 3 (6.06), those exposed to work harassment were up to 8.04 times more likely to have seen others being bullied in the last 6 months compared to those not exposed to work harassment. Similarly, 'conflicts in the workplace' odds ratios $\left(e^{\mathrm{b}}\right)$ for Level 1: Quite Difficult (3.54) and Level 2: Very Difficult (7.68) conflicts exposure indicated that those exposed to conflict in the workplace were up to 7.68 times more likely to have seen others being bullied in the last 6 months compared to those not exposed to conflicts above the usual level.

Table 2. Logistic Regression Analysis Parameters for Predicting the Outcome 'Seen Others Being Subjected to Bullying Behaviour at Work During the Previous Six Months'

\begin{tabular}{|c|c|c|c|c|c|c|c|c|}
\hline \multirow[t]{2}{*}{ Predictor } & \multirow[t]{2}{*}{$\beta$} & \multirow[t]{2}{*}{$S E \beta$} & \multirow{2}{*}{$\begin{array}{c}\text { Wald's } \\
\chi^{2}\end{array}$} & \multirow[t]{2}{*}{$d f$} & \multirow[t]{2}{*}{$p$} & \multirow{2}{*}{$\begin{array}{c}e^{\beta} \\
\text { odds ratio }\end{array}$} & \multicolumn{2}{|c|}{$95 \%$ CI for $e^{\beta}$} \\
\hline & & & & & & & Lower & Upper \\
\hline Constant & -2.72 & 0.81 & 11.42 & 1 & 0.001 & 0.07 & & \\
\hline Stress & 0.00 & 0.03 & 0.01 & 1 & 0.911 & 1.00 & 0.96 & 1.05 \\
\hline Alcohol & & & 1.91 & 2 & 0.551 & & & \\
\hline Alcohol (1) & -0.30 & 1.07 & 0.08 & 1 & 0.779 & 0.74 & 0.09 & 6.04 \\
\hline Alcohol (2) & 1.55 & 1.48 & 1.09 & 1 & 0.297 & 4.70 & 0.26 & 85.91 \\
\hline Atmosphere & 0.05 & 0.03 & 2.20 & 1 & 0.138 & 1.05 & 0.99 & 1.12 \\
\hline Sexual H. & & & 3.04 & 3 & 0.386 & & & \\
\hline Sexual H. (1) & -0.22 & 0.50 & 0.19 & 1 & 0.659 & 0.80 & 0.30 & 2.15 \\
\hline Sexual H. (2) & -1.19 & 0.83 & 2.09 & 1 & 0.148 & 0.30 & 0.06 & 1.53 \\
\hline Sexual H. (3) & -1.64 & 1.52 & 1.15 & 1 & 0.283 & 0.20 & 0.01 & 3.85 \\
\hline Burnout & & & 1.42 & 2 & 0.491 & & & \\
\hline Burnout (1) & -0.13 & 0.42 & 0.10 & 1 & 0.758 & 0.88 & 0.39 & 1.99 \\
\hline Burnout (2) & -0.77 & 0.67 & 1.33 & 1 & 0.249 & 0.46 & 0.13 & 1.71 \\
\hline W. Conflict & & & 14.09 & 2 & 0.001 & & & \\
\hline W. Conflict (1) & 1.26 & 0.38 & 10.91 & 1 & 0.001 & 3.54 & 1.67 & 7.49 \\
\hline W. Conflict (2) & 2.04 & 0.75 & 7.47 & 1 & 0.006 & 7.68 & 1.78 & 33.10 \\
\hline Work H. & & & 18.87 & 3 & 0.000 & & & \\
\hline Work H. (1) & 1.60 & 0.43 & 13.96 & 1 & 0.000 & 4.96 & 2.14 & 11.49 \\
\hline Work H. (2) & 2.09 & 0.63 & 11.09 & 1 & 0.001 & 8.04 & 2.36 & 27.45 \\
\hline Work H. (3) & 1.80 & 1.06 & 2.88 & 1 & 0.089 & 6.06 & 0.76 & 48.49 \\
\hline
\end{tabular}

Third, in relation to the third predicted outcome variable (i.e., having been bullied previously in their career), the collective influence of the hypothesised antecedent variables was significant $\left(\chi^{2}=116.86\right.$, df $\left.=14, \mathrm{p}<0.001\right)$. Statistically significant relationships were found in relation to Work Harassment (Wald $\left.\chi^{2}=35.65, \mathrm{df}=3, \mathrm{p}<0.001\right)$ (Björkqvist \& Österman, 1992d), 'conflicts in the 
workplace' (Wald $\left.\chi^{2}=6.42, \mathrm{df}=2, \mathrm{p}<0.05\right)$ (Björkqvist \& Österman, 1992d), 'work stress symptoms' (Wald $\chi^{2}=5.65, \mathrm{df}=1, \mathrm{p}<0.05$ ) (Björkqvist \& Österman, 1992c), and 'alcohol abuse' (Wald $\chi^{2}=8.15$, df $=2, \mathrm{p}<0.05$ ) (Björkqvist \& Österman, 1992d) (See Table 3). In relation to 'exposure to work harassment' odds ratios $\left(e^{\mathrm{b}}\right)$ for Level 1 (27.34), Level 2 (33.33), and Level 3 (17.26), those exposed to work harassment were up to 33.33 times more likely to have seen others being bullied previously in their career compared to those not exposed to work harassment. Similarly, 'conflicts in the workplace' odds ratios $\left(e^{\mathrm{b}}\right)$ for Level 1: Quite Difficult (2.59) and Level 2: Very Difficult (0.72) conflicts exposure indicated that those exposed to conflict in the workplace were up to 2.59 times more likely to have been bullied previously in their career compared to those not exposed to conflicts above the usual level. In relation to 'work stress symptoms' odds ratio $\left(e^{\mathrm{b}}\right)$, those showing more stress symptoms were 1.07 times more likely to have been bullied previously in their career compared to those showing less symptoms of stress. Finally, 'alcohol abuse' odds ratios $\left(e^{\mathrm{b}}\right)$ for Level 1: absence due to hangover (0.03) and Level 2: appeared drunk at times in the workplace (3.54) indicated those reporting drunkenness in the workplace were 3.54 times more likely to have been bullied previously in their career compared to those not reporting issues related to alcohol abuse.

Table 3. Logistic Regression Analysis Parameters for Predicting the Outcome 'Been Bullied Previously in Their Career'

\begin{tabular}{lrrrrrrrr}
\hline Predictor & $\beta$ & $S E \beta$ & Wald's & $d f$ & $p$ & $e^{\beta}$ & \multicolumn{2}{c}{$95 \%$ CI for $e^{\beta}$} \\
& & & \multicolumn{1}{c}{$\chi^{2}$} & & & odds ratio & Lower & Upper \\
\hline Constant & -0.87 & 0.80 & 1.20 & 1 & 0.273 & 0.42 & & \\
Stress & 0.07 & 0.03 & 5.65 & 1 & 0.018 & 1.07 & 1.01 & 1.14 \\
Alcohol & & & 8.15 & 2 & 0.017 & & & \\
Alcohol (1) & -3.65 & 1.34 & 7.41 & 1 & 0.006 & 0.03 & 0.00 & 0.36 \\
Alcohol (2) & 1.27 & 1.51 & 0.70 & 1 & 0.404 & 3.54 & 0.18 & 68.90 \\
Atmosphere & -0.03 & 0.04 & 0.87 & 1 & 0.352 & 0.97 & 0.90 & 1.04 \\
Sexual H. & & & 0.71 & 3 & 0.872 & & & \\
Sexual H. (1) & 0.44 & 0.59 & 0.56 & 1 & 0.453 & 1.55 & 0.49 & 4.91 \\
Sexual H. (2) & -0.28 & 0.99 & 0.08 & 1 & 0.775 & 0.75 & 0.11 & 5.28 \\
Sexual H. (3) & 0.09 & 1.54 & 0.00 & 1 & 0.953 & 1.10 & 0.05 & 22.54 \\
Burnout & & & 2.30 & 2 & 0.316 & & & \\
Burnout (1) & -0.68 & 0.46 & 2.26 & 1 & 0.133 & 0.51 & 0.21 & 1.23 \\
Burnout (2) & -0.65 & 0.85 & 0.58 & 1 & 0.448 & 0.52 & 0.10 & 2.79 \\
W. Conflict & & & 6.42 & 2 & 0.040 & & & \\
W. Conflict (1) & 0.95 & 0.43 & 4.93 & 1 & 0.026 & 2.59 & 1.12 & 5.98 \\
W. Conflict (2) & -0.33 & 0.78 & 0.18 & 1 & 0.671 & 0.72 & 0.16 & 3.31 \\
Work H. & & & 35.65 & 3 & 0.000 & & & \\
Work H. (1) & 3.31 & 0.61 & 29.26 & 1 & 0.000 & 27.34 & 8.25 & 90.66 \\
Work H. (2) & 3.51 & 1.00 & 12.24 & 1 & 0.000 & 33.33 & 4.68 & 237.58 \\
Work H. (3) & 2.85 & 1.28 & 4.99 & 1 & 0.026 & 17.26 & 1.42 & 210.21 \\
\hline
\end{tabular}




\section{Work and life attitudes}

The third aim of the current research was to explore whether respondents' answers to the three questions regarding personal experience of bullying behaviour would be predictor variables in relation to outcome variables related to 'Work and Life Attitudes' (i.e., work involvement, intrinsic job motivation, job satisfaction, self-rated anxiety, life satisfaction, interpersonal trust at work, organizational commitment, and self-esteem (trait and state).

Thus, respondents' responses regarding these variables were regressed upon responses to the three questions relating to personal experience of bullying behaviours in the workplace using a series of linear regressions.

The collective influence of the hypothesised predictor variables (i.e., the three questions relating to personal experience of bullying behaviours in the workplace) on the hypothesised outcome variables was explored. It was found that these predictor variables explained a significant proportion of the variance in relation to Work Stress (Björkqvist \& Österman, 1992d) (adjusted $\mathrm{r}^{2}=0.22$ ), Self-Esteem (trait: Rosenberg, 1965) (adjusted $\mathrm{r}^{2}=0.02$ ), Self-Esteem (state: Heatherton \& Polivy, 1991) (adjusted $r^{2}=0.06$ ), Job Satisfaction (Warr et al., 1979) (adjusted $r^{2}$ $=0.16$ ), Self-Rated Anxiety (Warr et al., 1979) (adjusted $\left.r^{2}=0.08\right)$, Interpersonal Trust at Work (Cook \& Wall, 1980) (adjusted $r^{2}=0.11$ ), and Life Satisfaction (Warr et al., 1979) (adjusted $r^{2}=0.05$ ).

In relation to the first of these predictor variables (i.e., having been bullied in the previous six months), statistically significant relationships were uncovered in relation to Work Stress (Björkqvist \& Österman, 1992d) (Standardized b = $0.28, \mathrm{p}<0.01$ ), Self-Esteem (trait: Rosenberg, 1965) (Standardized b $=-0.14, \mathrm{p}$ $<0.05$ ), Job Satisfaction (Warr et al., 1979) (Standardized $b=-0.25, p<0.05$ ), Self-Rated Anxiety (Warr et al., 1979) (Standardized b $=0.17, \mathrm{p}<0.05$ ), and Interpersonal Trust at Work (Cook \& Wall, 1980) (Standardized b $=-0.26, \mathrm{p}<$ $0.01)$.

In relation to the second of these predictor variables (i.e., having seen others being subjected to bullying during the last six months), a statistically significant relationship was uncovered in relation to Self-Esteem (state: Heatherton \& Polivy, 1991) (Standardized $b=-0.14, p<0.05$ ).

In relation to the third of these predictor variables (i.e., having been bullied previously in career), statistically significant relationships were uncovered in relation to Work Stress (Björkqvist \& Österman, 1992d) (Standardized b $=0.25, \mathrm{p}$ $<0.01$ ), Job Satisfaction (Warr et al., 1979) (Standardized b $=-0.19, \mathrm{p}<0.01$ ), Self-Rated Anxiety (Warr et al., 1979) (Standardized b $=0.18, \mathrm{p}<0.01$ ), and Life Satisfaction (Warr et al., 1979) (Standardized $b=-0.16, p<0.05$ ).

\section{DISCUSSION}

In extending previous research in the area, the current study had three related aims. First, to explore the level of personal experience of workplace bullying 
among a sample of adults returning to either full- or part-time tertiary education. Second, to examine the relationship between the 'psychosocial work environment' and personal experience of workplace bullying. Third, to examine the relationship between personal experience of workplace bullying and salient 'work and life attitudes'.

In terms of personal experience of workplace bullying, $32.4 \%$ of respondents had been bullied in the 'previous six months', a further $42.1 \%$ had witnessed a colleague being bullied during this time-reference period, and $56.8 \%$ had been bullied previously in their career. Directly comparable data $(46.9 \%, 55.1 \%$, $57.6 \%$ ) provided by Mc Guckin et al. (under review) from their research among nurses demonstrates that personal experience of workplace bullying among this more occupationally diverse sample was also a significant experience of working life. These data are higher than the American data reported by Keashly et al. (1994) and the English data reported by Rayner (1997). Indeed, compared to previous national level studies (e.g., Sweden, Norway, Finland, Austria, UK, Ireland), these data demonstrate the significantly high level of personal exposure to workplace bullying among the respondents. For example, utilising a directly comparable time-reference period (6 months) in their national study in Ireland, the Health and Safety Authority (2001) found that 7\% of respondents reported being the victim of workplace bullying. It is possible that the higher rates of experience found in this study are in some way indicative of a substantial difference in experiences, expectations, and attitudes regarding the workplace by those who have either a need or confidence to leave the workplace and seek mobility through educational qualifications. Further research would be required among workers to determine how various sub-groups view the workplace and the expectations they have of it (e.g., psychological contract). Considering the increasing return rate to tertiary education of 'non-traditional students', and the differing demands placed upon on university structures by these students (Dill \& Henley, 1998) (e.g., student services, counselling support), university managers should be cognisant of the prior experiences, both positive and negative, these students bring with them to their college career. Indeed, employers who seek to maintain good staff relations and retention, especially in times of economic downturn, should also be cognisant of the role that workplace bullying may play in the decision making process regarding the choice to return to tertiary education. Whilst these data highlight the high level of personal experience of workplace bullying among returning tertiary students, future research may wish to include other suitably robust measures that can appropriately assess experience of workplace bullying (e.g., the Leymann Inventory of Psychological Terrorization: Leymann, 1990b [see Cowie, Naylor, Rivers, Smith, \& Pereira, 2002 for a review]; the Negative Acts Questionnaire-Revised: Einarsen \& Höel, 2001; Einarsen \& Raknes, 1997; Höel et al., 2001), as well as theoretically derived measures to aid understanding of how individuals decide to return to education (e.g., Theory of Planned Behaviour: Ajzen, 1991).

The second aim of the current research was to extend previous research that 
has explored the role of the work environment hypothesis in the workplace bullying phenomenon (e.g., Einarsen et al., 1994; Mc Guckin et al., under review) by examining the relationship between the psychosocial workplace and personal experience of workplace bullying. The current research found that the collective influence of the hypothesised antecedent variables (i.e., work harassment, sexual harassment, atmosphere, stress, conflict, burnout, and alcohol abuse) explained a significant proportion of the variance in relation to self-reported personal experience of workplace bullying (i.e., been bullied in the previous six months, witnessed bullying in this period, been bullied previously). This data confirms and extends the previous work of Varhama and Björkqvist (2004a, b) and Varhama et al. (2010) who have highlighted the role of the 'psychosocial work environment' in workplace bullying among samples of Finnish, Polish, and Spanish employees. Indeed, these data also confirm the suggestion by Mc Guckin et al. (under review) that as well as the 'work environment hypothesis', the 'psychosocial work environment' may also act as antecedent in the bullying process. Future research in the area should seek to fully explore the role of both the 'work environment hypothesis' and the 'psychosocial work environment' simultaneously. Such research could fruitfully identify the most salient variables within each of these propositions. Such an answer would be beneficial in that a more parsimonious solution could be identified for future research endeavors that seek inclusion of more predictive 'a priori' antecedent variables.

In an extension of the work of Mc Guckin et al. (under review), the third aim of the current research was to explore whether personal experience of workplace bullying was predictive of the individual's work and life attitudes. The collective influence of the hypothesised predictor variables (i.e., the three questions relating to personal experience of bullying behaviours) explained a significant proportion of the variance in relation to self-reported work and life attitudes (i.e., work stress, state self-esteem, job satisfaction, self-rated anxiety, interpersonal trust at work, life satisfaction). Of the three predictor variables, it was found that 'personal' experience of bullying had a more direct impact on work and life attitudes than experience of 'witnessing' the harassment of others. This data confirms and extends the previous work of Mc Guckin et al. (under review) who have demonstrated the impact of personal experience of workplace bullying on these significant work and life attitudes. In doing so, the current research supports Brodsky's (1976) early warning that "the effects of harassment upon its victims can be devastating" (p. 38). Future research should seek to explore other contemporary issues for those in the workforce (e.g., work-life balance). Indeed, future research should also seek to explore the possible 'spill-over effect' of the consequences of workplace bullying to the individual's home and family life.

With the 'widening participation' agenda in tertiary education, increasing numbers of adults are returning to life-long learning programmes of study that are designed to be transferrable and portable throughout the European higher education arena. Coupled with a volatile employment market, the traditional focus of such institutions on the learning and personal requirements of 'traditional' 
students should be further developed so as to be cognisant of the requirements of these returning 'non-traditional' students. Indeed, in recognition of the toxic nature of some workplaces, employer and worker representative groups should continue to strive for policy and practice agreement regarding the issue of workplace bullying. Such agreement may aid in the fostering of open and harmonious workplaces that are productive for business and worker alike. Indeed, whilst some such liaisons between these stakeholders and government have taken place (e.g., Ireland's Social Partnership approach), only robust, identifiable, and implemented laws and procedures for dealing with workplace bullying will offer the worker the protection from harm and harassment that they deserve in relation to the protection of their dignity at work (Forde \& Mc Guckin, 2009).

In conclusion, these findings provide further data regarding the incidence of workplace bullying and the relationships between such personal experience and potential 'trigger' factors in the psychosocial work environment, as well as the insidious effects of exposure to such behaviours on the workforce. Such findings are a cause for concern for employers (e.g., health and safety, retention, recruitment), business organizations (e.g., Institutes of Directors, Trades Unions), and tertiary education institutions (e.g., pastoral care, student support).

\section{REFERENCES}

Ajzen, I. (1991). The theory of planned behaviour. Organisational Behaviour and Human Decision Processes, 50, 179-211. doi:10.1016/0749-5978(91)90020-T

Barker, E. D., Arseneault, L., Brendgen, M., Fontaine, N., and Maughan, B. (2008). Joint development of bullying and victimization in adolescence: Relations to delinquency and self-harm. Journal of the American Academy of Child \& Adolescent Psychiatry, 47, 1030-1038. doi:10.1097/CHI. ObO13e31817eec98

Björkqvist, K. (1992). Trakassering förekommer bland anställda vid $\AA$ [Harassment exists among employees at Abo Academy]. Meddelande från Abo Akademi, 9, 14-17.

Björkqvist, K., \& Österman, K. (1992a). The Work Harassment Scale. In K. Björkqvist, K. M. J. Lagerspetz \& K. Österman (Eds.), Scales for research on interpersonal relations. Pro Faculate, No. 4. Vasa, Finland: Department of Social Sciences, Åbo Akademi University.

Björkqvist, K., \& Österman, K. (1992b). The Work Atmosphere Scale. In K. Björkqvist,K. M. J. Lagerspetz \& K. Österman (Eds.), Scales for research on interpersonal relations. Pro Faculate, No. 4. Vasa, Finland: Department of Social Sciences, Åbo Akademi University.

Björkqvist, K., \& Österman, K. (1992c). The Work Stress Symptom Scale. In K. Björkqvist, K. M. J. Lagerspetz \& K. Österman (Eds.), Scales for research on interpersonal relations. Pro Faculate, No. 4. Vasa, Finland: Department of

Social Sciences, Åbo Akademi University.

Björkqvist, K., and Österman, K. (1992d). The Psychosocial Workplace Inven- 
tory. In K. Björkqvist, K. M. J. Lagerspetz and K. Österman (Eds.), Scales for research on interpersonal relations. Pro Faculate, No. 4. Vasa, Finland: Department of Social Sciences, Åbo Akademi University.

Björkqvist, K., Österman, K., and Hjelt-Bäck, M. (1994). Aggression among university employees. Aggressive Behavior, 20, 173-184. doi:10.1002/10982337(1994)20:3<173::AID-AB2480200304>3.0.CO;2-D

Björkqvist, K., Österman, K., Ingo, A., and Varhama, L. M. (2007). Validity testing of the Psychosocial Workplace Inventory. Unpublished. Vasa, Finland: Department of Social Sciences, Åbo Akademi University.

Bond, F. W., and Bunce, D. (2000). Mediators of change in emotion-focused and problem focused worksite stress management interventions. Journal of Occupational Health Psychology, 5, 156-163. doi: 10.1037//1076-8998.5.1.156

Breen, A., and Mc Namara, M. (2004, June). An investigation into workplace bullying and organisational culture in healthcare within an Irish hospital setting. Paper presented at the Proceedings of the fourth international conference on bullying and harassment in the workplace (pp. 35-36). Bergen, Norway.

Brodsky, C. M. (1976). The harassed worker. Toronto: Lexington Books, DC Heath.

Brunstein Klomek, A., Marrocco, F., Kleinman, M., Schonfeld, I. S., and Gould, M. S. (2007). Bullying, depression, and suicidality in adolescents. Journal of the American Academy of Child \& Adolescent Psychiatry, 46, 40-49. http:// dx.doi.org/10.1097/01.chi.0000242237.84925.18

Cook, J., and Wall, T. (1980). New work attitude measures of trust, organizational commitment and personal need non-fulfilment. Journal of Occupational Psychology, 53, 39-52. doi: 10.1111/j.2044-8325.1980.tb00005.x

Cook, C. R., Williams, K. R., Guerra, N. G., Kim, T. E., and Sadek, S. (2010). Predictors of bullying and victimization in childhood and adolescence: A meta-analytic investigation. School Psychology Quarterly, 25, 65-83. doi: 10.1037/a0020149

Cowie, H., Naylor, P., Rivers, I., Smith, P. K., \& Pereira, B. (2002). Measuring workplace bullying. Aggression and Violent Behaviour, 7, 33-51. doi:10.1016/ S1359-1789(00)00034-3

Coyne, I., Seigne, S., and Randall, P. (2000). Predicting workplace victim status from personality. European Journal of Work and Organizational Psychology, 9, 335-349. doi: 10.1080/135943200417957

Cox, T. (2005, September). Risk management: Tackling psychosocial \& organisational problems. Paper presented at The British Psychological Society conference: Working together to tackle workplace bullying: Concepts, research and solutions. Portsmouth Business School, University of Portsmouth.

Department for Education and Skills (2003). The future of higher education (White Paper). London: Her Majesty's Stationery Office.

Dill, P. L., and Henley, T. B. (1998). Stressors of college: A comparison of traditional and non traditional students. Journal of Psychology, 132, 25-33. http:// dx.doi.org/10.1080/00223989809599261dos Santos Palazzo, L., Carlotto, M. 
S., \& D. R. G. de Castro (2012). Burnout syndrome: Population-based study on public servants. Rev. Saúde Pública, 46(6), 1066-1073. http://dx.doi. org/10.1590/S0034-89102013005000004

Einarsen, S. (1996). Bullying and harassment at work: Epidemiological and psychosocial aspects. PhD Thesis, Department of Psychosocial Science, University of Bergen, Norway.

Einarsen, S. (1999). The nature and causes of bullying at work. International Journal of Manpower, 20, 16-27. doi: 10.1108/01437729910268588

Einarsen, S. (2000). Harassment and bullying at work: A review of the Scandinavian approach. Aggression and Violent Behavior, 5, 379-401. doi:10.1016/ S1359-1789(98)00043-3

Einarsen, S., and Höel, H. (2001, May). The Negative Acts Questionnaire: Development, validation, and revision of a measure of bullying at work. Paper presented at the 10th European Congress on Work and Organisational Psychology, Prague, Czech Republic.

Einarsen, S., Höel, H., Zapf, D., and Cooper, C. (Eds.) (2003). Bullying and emotional abuse in the workplace: International perspectives in research and practice. London: Taylor and Francis.

Einarsen, S., Matthiesen, S., and Skogstad, A. (1998). Bullying, burnout and well-being among assistant nurses. Journal of Occupational Health and Safety: Australia and New Zealand, 14, 563-568.

Einarsen, S., \& Raknes, B. I. (1997). Harassment at work and the victimization of men. Violence and Victims, 12, 247-263.

Einarsen, S., Raknes, B. I., \& Matthiesen, S. B. (1994). Bullying and harassment at work and their relationship to work environment quality: An exploratory study. The European Work and Organizational Psychologist, 4, 381-401. doi:10.1080/13594329408410497

Einarsen, S., Raknes, B. I., Matthiesen, S. B., and Hellesøy, O. H. (1996). Bullying at work and its relationships with health complaints. Moderating effects of social support and personality. Nordisk Psykologi, 48, 116-137.

Fleming, J. S., and Courtney, B. E. (1984). The dimensionality of self-esteem. II: Hierarchical facet model for revised measurement scales. Journal of Personality and Social Psychology, 46, 404-421. doi: 10.1037/0022-3514.46.2.404

Forde, C., \& Mc Guckin, C. (2009). Combating workplace bullying: A holistic approach to a better understanding. The Psychological Society of Ireland Annual Conference, Whites Hotel, Wexford, Co. Wexford, Ireland, 5th-8th November, 2009. The Irish Psychologist, 35, 416.

Health and Safety Authority (2001). Dignity at work: The challenge of workplace bullying. Report of the Task Force on the Prevention of Workplace Bullying. Dublin, Ireland: The Stationery Office.

Heatherton, T. F., and Polivy, J. (1991). Development and validation of a scale for measuring state self-esteem. Journal of Personality and Social Psychology, 60(6), 895-910. doi: 10.1037/0022-3514.60.6.895

Hermann, B. A. (2008). Dismantling an act-based intervention for work stress: 
Do values really matter? Ph.D. Thesis, The Graduate School, The University of Maine.

Higher Education Authority (2009). Higher education: Key facts and figures 07/08. Dublin: Higher Education Authority.

Hodges, E. V. E., and Perry, D. G. (1999). Personal and Interpersonal Antecedents and Consequences of Victimization by Peers. Journal of Personality and Social Psychology, 76, 677-685. doi: 10.1037/0022-3514.76.4.677

Höel,H., Cooper, C.L., and Faragher,B.(2001). The experience of bullying in Great Britain: The impact of organizational status. European Journal of Work and Organizational Psychology, 10, 443-465. doi:10.1080/13594320143000780

Kaltiala-Heino, R., Rimpela, M., Rantanen, P., and Rimpela, A. (2000). Bullying - an indicator to detect adolescents at risk for mental disorders. Journal of Adolescence, 23, 661-674. doi:10.1006/jado.2000.0351

Keashly, L., Trott, V., and MacLean, L. M. (1994). Abusive behavior in the workplace: A preliminary investigation. Violence and Victims, 9(4), 341-357.

Keith, L. K., and Bracken, B. A. (1996). Self-concept instrumentation: A historical and evaluative review. In B. A. Bracken (Eds.), Handbook of self-concept: Developmental, social, and clinical considerations (pp. 91-170). New York: John Wiley and Sons, Inc.

Kivimäki, M., Virtanen, M., Vartia, M., Elovainio, M., Vahtera, J., and Keltikangas-Järvinen, L. (2003). Workplace bullying and the risk of cardiovascular disease and depression. Occupational Environmental Medicine, 60, 779-783. doi:10.1136/oem.60.10.779

Leymann, H. (1988). Ingen annan utvag [No way out]. Stockholm: Wahlstrom \& Widstrand.

Leymann, H. (1990a). Mobbing and psychological terror at workplaces. Violence and Victims, 5, 119-126.

Leymann, H. (1990b). Handbok for anvandning av LIPT-formularet for kartlaggning av risker for psykist vald arbetsmiljon [The LIPT questionnaire - a manual]. Stockholm: Violen.

Leymann, H. (1992). Fran mobbning til utslagning I arbetslivet [From bullying to exclusion from working life]. Stockholm: Publica.

Leymann, H. (1996). The content and development of bullying at work. European Journal of Work and Organizational Psychology, 5, 165-184. doi:10.1080/13594329608414853

Leymann, H., and Gustafsson, A. (1996). Mobbing at work and the development of post-traumatic stress disorders. European Journal of Work and Organizational Psychology, 5, 251-275. doi:10.1080/13594329608414858

Lin, Yu-Hui (2007). Understanding school bullying and workplace abuse in a Taiwanese context. PhD Thesis, Oregon State University.

Lund, R., Nielsen, K. K., Hansen, D. H., Kriegbaum, M., Molbo, D., Due, P., et al. (2009). Exposure to bullying at school and depression in adulthood: A study of Danish men born in 1953. The European Journal of Public Health, 19,111 . 
Lynch, J., and O’Moore, M. (2004, June). Workplace bullying: Psychological effects, coping strategies and personality constructs of recipients of bullying behaviours. Paper presented at the proceedings of the fourth international conference on bullying and harassment in the workplace (pp. 82-84). Bergen, Norway.

Mc Guckin, C., Lewis, C. A., and Shevlin, M. (under review). Workplace bullying among nurses: A structural model of the work environment and work and life attitudes.

Mikkelsen, E. G., and Einarsen, S. (2002). Basic assumptions and symptoms of post-traumatic stress among victims of bullying at work. European Journal of Work and Organizational Psychology, 11, 87-111. doi:10.1080/13594320143000861

Niedl, K. (1995). Mobbing/bullying am Arbeitsplatz. Eine empirische Analyse zum Phänomen sowie zu personalwirtschaftlich relevanten Effekten von systematischen Feindseligkeiten [Mobbing/bullying at work: An empirical analysis of the phenomenon and of the effects of systematic hostilities relevant for human resource issues]. Munchen: Rainer Hampp Verlag.

Niedl, K. (1996). Mobbing and well-being: Economic and personnel development implications. European Journal of Work and Organizational Psychology, 5, 239-249. doi:10.1080/13594329608414857

Olweus, D. (1991). Bully / victim problems among schoolchildren: Basic facts and effects of a school-based intervention program. In D. J. Pepler and K. H. Rubin (Eds.), The Development and Treatment of Childhood Aggression (pp. 411-448). Hillsdale, New Jersey: Lawrence Erlbaum.

O’Moore, M., Seigne, E., Mc Guire, L, and Smith, M. (1998). Victims of workplace bullying in Ireland. The Irish Journal of Psychology, 19, 345-357. doi: 10.1080/03033910.1998.10558195

Quine, L. (1999). Workplace bullying in NHS Community Trust: Staff questionnaire survey. British Medical Journal, 318, 228-232. doi: http://dx.doi. org/10.1136/bmj.318.7178.228

Rayner, C. (1997). The incidence of workplace bullying. Journal of Community \& Applied Psychology, 7, 199-208. doi: 10.1002/(SICI)10991298(199706)7:3<199::AID-CASP418>3.0.CO;2-H

Rigby, K. (2002). New perspectives on bullying. London: Jessica Kingsley.

Rigby, K. (2001). Health consequences of bullying and its prevention in schools. In J. Juvonen \& S. Graham (Eds.), Peer harassment in school: The plight of the vulnerable and victimized (pp. 310-331). New York: Guilford.

Rosenberg, M. (1965). Society and the adolescent self-image. Princeton, New Jersey: Princeton University Press.

Salmivalli, C. (2001). Group view on victimization-Empirical findings and their implications. In J. Juvonen \& S. Graham (Eds.), Peer harassment in school: The plight of the vulnerable and victimized (pp. 398-419). New York: Guilford Press.

Seigne, E. (1998, July). Bullying at work in Ireland. Paper presented at the Bu- 
llying at work: 1998 research update conference - proceedings. Staffordshire, United Kingdom: Staffordshire University Business School.

Silber, E., \& Tippett, J. (1965). Self-esteem: Clinical assessment and measurement validation. Psychological Reports, 16, 1017-1071. doi: 10.2466/ pr0.1965.16.3c.1017

Smith, P. K., Singer, M., Höel, H., \& Cooper, C. L. (2003). Victimization in the school and the workplace: Are there any links? British Journal of Psychology, 95, 175-188. doi:10.1348/000712603321661868

Thomas, W. (2001). The decision to return to full-time education. Education Economics, 9, 37-51. doi:10.1080/09645290125092

Thylefors, I. (1987). Syndabockar. Om utstotning och mobbning I arbetslivet [Scapegoats. On exclusions and bullying in working life]. Stockholm: Naturoch Kultur.

Varhama, L. M., and Björkqvist, K. (2004a). Conflicts, burnout, and bullying in a Finnish and a Polish company: a cross-national comparison. Perceptual and Motor Skills, 98, 1234-1240. doi: 10.2466/pms.98.3c.1234-1240

Varhama, L. M., and Björkqvist, K. (2004b). Conflicts, workplace bullying and burnout problems among municipal employees. Psychological Reports, 94, 1116-1124. doi: 10.2466/PR0.94.3.1116-1124

Varhama, L. M., Báguena, M. J., Beleña, M. A., Roldán, M. C., Diaz, A., Österman, K., and Björkqvist, K. (2010). Dysfunctional workplace behavior among municipal employees in Spanish and a Finnish city: a cross-national comparison. Perceptual and Motor Skills, 110, 463-468. doi: 10.2466/ pms.110.2.463-468

Vartia, M. (1991). Bullying at workplaces. In S. Lehtinene, J. Rantanen, P. Juuti, A. Koskela, K. Lindström, P. Rehnström, and J. Saari (Eds.), Towards the $21^{\text {st }}$ Century: Work in the 1990's: Proceedings from the international symposium on future trends in the changing working life (pp. 131-135). Helsinki: Institute of Occupational Health.

Vartia, M. (1996). The sources of bullying - Psychological work environment and organizational climate. European Journal of Work and Organizational Psychology, 5, 203-214. doi:10.1080/13594329608414855

Vartia, M., and Hyyti, J. (2002). Gender differences in workplace bullying among prison officers. European Journal of Work and Organizational Psychology, 11, 113-126. doi:10.1080/13594320143000870

Voss, M., Floderus, B., \& Diderichsen, F. (2001). Physical, psychosocial, and organizational factors relative to sickness absence: A study based on Sweden post. Occupational Environmental Medicine, 58, 178-184. doi:10.1136/ oem.58.3.178

Warr, P., Cook, J., and Wall, T. (1979). Scales for the measurement of some work attitudes and aspects of psychological well-being. Journal of Occupational Psychology, 52, 129-148. doi: 10.1111/j.2044-8325.1979.tb00448.x

Wylie, R. C. (1989). Measures of self-concept. Lincoln: University of Nebraska Press. 
Zapf, D. (1999). Organisational, work group related and personal causes of mobbing/bullying at work. International Journal of Manpower, 20, 70-85. doi: 10.1108/01437729910268669

Zapf, D., Knorz, C., and Kulla, M. (1996). On the relationship between mobbing factors and job content, social work environment, and health outcomes. European Journal of Work and Organizational Psychology, 5, 215-37. doi: $10.1080 / 13594329608414856$ 